\title{
ENGAJAMENTO POLÍTICO, COMPETÊNCIA TÉCNICA E ELITES DIRIGENTES DO MOVIMENTO AMBIENTALISTA
}

\author{
Wilson José Ferreira de Oliveira
}

\begin{abstract}
RESUMO
Este artigo examina as condições e as dinâmicas de utilização de competências peritas na militância política. No que pese as diferenças de abordagens, um dos temas constantes tanto na literatura nacional quanto na internacional, diz respeito à importância crescente dos recursos escolares e da legitimidade perita no recrutamento e seleção para os postos de direção em organizações ambientalistas. Com base numa investigação sobre os principais dirigentes das mobilizações e organizações ambientalistas entre a década de 1970-2004, pretende-se evidenciar a hipótese de que a utilização dessas competências no exercício de funções dirigentes resulta de dinâmicas de diversificação do ensino superior e da maior articulação entre formação escolar e engajamento político, por meio da inserção em diversas redes de organizações e "movimentos sociais" no decorrer de seus itinerários familiares, escolares, políticos e profissionais. Os procedimentos metodológicos utilizados para dar conta disso, consistiram na realização de 50 entrevistas biográficas com dirigentes de diferentes tipos de associações ambientalistas, com vistas à apreensão dos itinerários que os conduziram ao engajamento político, dos significados atribuídos à formação profissional $e$ dos tipos de recursos e de vínculos sociais que respaldam suas concepções e práticas militantes. As principais conclusões obtidas demonstram que, ao invés da imposição de um "militância perita”, o característico da situação analisada é uma forte imbricação do exercício de funções peritas no ambientalismo com a inserção simultânea em múltiplas redes de organizações e "movimentos sociais" e a ocupação de postos em diferentes esferas sociais com base nos recursos e vinculações políticas acumuladas por meio de tais inserções.
\end{abstract}

PALAVRAS-CHAVE: elites dirigentes; militância; engajamento; participação política; competência técnica; ambientalismo.

\section{INTRODUÇÃO}

Um dos principais problemas que estão em pauta nas análises atuais de diferentes formas de militância diz respeito à importância e aos efeitos da escolarização sobre o associativismo e à configuração de uma militância que têm como base principal "a escola”: militantes com elevada formação escolar e cuja intervenção está amplamente respaldada na utilização de recursos escolares e peritos. Nesse sentido, a maioria dos trabalhos sobre militância tem salientado que a expansão da escolarização pode ser tomada como um dos principais ingredientes das transformações atuais da militância. Assim, as análises produzidas sobre a militância na defesa dos direitos humanos, de causas humanitárias, sindicais, ambientalistas, entre outros, têm demonstrado que a importância crescente dos recursos escolares e da legitimidade perita nas mobilizações coletivas pode ser tomada como uma característica principal dos mais diferentes tipos de militância. Associado a isso, o peso crescente da escolarização no exercício da militância tem sido abordado como uma das principais modificações relacionadas à tendência geral de institucionalização da ação associativa, no sentido de regularização de seu acesso aos espaços e aos processos formais de produção de políticas públicas, assim como de profissionalização de seus integrantes e de suas atividades. Segundo tais análises, a participação regular das organizações não-governamentais (ONGs) em instâncias formais (conselhos, fóruns, comitês etc.) esteve associada ao recrutamento de militantes e dirigentes dotados de elevada formação técnica e científica e à utilização de competências técnicas, adquiridas por meio da formação universitária, como um dos principais recursos militantes nas intervenções públicas de tais organizações, possibilitando o surgimento de um novo campo 
de exercício profissional (SIMÉANT \& DAUVIN, 2002; MATONTI \& POUPEAU, 2004; WAGNER, 2004).

É também com base em tais considerações que se tem analisado a importância e os efeitos da escolarização sobre a militância ambientalista. Ou seja, longe de constituir-se como uma característica própria ou exclusiva da participação na defesa de causas ambientais, essa tem sido apresentada como uma das situações exemplares para a observação da forte imbricação entre perícia e engajamento político. Nesse sentido, alguns trabalhos têm salientado a importância da formação técnica e científica no recrutamento e na seleção dos dirigentes ambientalistas, resultando na constituição de uma categoria social que tem como um dos traços principais o fato de ser fortemente dotada em capitais cultural, escolar, profissional e social: alta representação de diplomados, forte presença de categorias intelectuais, de universitários ou de pesquisadores e relações de afinidade e de inter-reconhecimento com atores do universo científico, político, sindical e midiático (OLLITRAULT, 1996). A respeito disso, Ollitrault (2001) salienta que uma das principais transformações ocorridas nesse tipo de militância a partir de meados da década de 1980 foi a substituição de um modelo de "militante ativista" pelo "militante perito". De maneira similar, Gallet (2002) demonstra que a utilização de "recursos peritos" tornou-se um dos instrumentos principais do ativismo ambiental e guiou a reestruturação do Greenpeace francês em sua estratégia de mobilização coletiva. Tais características escolares dos dirigentes são consideradas como um dos fatores principais que possibilita compreender a grande "circularidade" entre os discursos eruditos e militantes no universo do ambientalismo que se manifesta, entre outras coisas, por meio de uma ambigüidade extremamente forte entre as categorias científicas e militantes. Ela está fundada na capacidade que os "ecologistas" têm de utilização instrumental de recursos escolares e acadêmicos em proveito de sua luta militante, apropriando-se de análises científicas para justificar suas condutas e legitimar suas posições militantes, produzindo eles mesmos os seus discursos identitários, os quadros teóricos, os esquemas de interpretação e de avaliação do "movimento ecologista”, bem como definindo os problemas ecológicos a considerar e as soluções a adotar (HANNIGAN, 1995; OLLITRAULT, 1996).
Este trabalho insere-se nessa problemática de investigação mais geral referente às relações entre perícia e militância. Examinam-se as condições e as lógicas sociais que respaldam os usos e a reconversão da formação escolar e universitária para a ocupação de cargos e funções dirigentes em organizações e instâncias de proteção ambiental, focalizando as concepções de sociedade e de política que fundamentam as definições da atividade profissional, assim como os tipos de recursos e de vínculos sociais e políticos associados ao seu exercício. Parte-se do princípio de que a ocupação de cargos e posições profissionais não constitui um resultado direto da formação escolar e universitária adquirida, sendo antes mediada por dinâmicas estruturais e objetivas, bem como por recursos, disposições e concepções constituídas no transcurso de diferentes tipos de socialização (familiar, escolar, política, profissional etc.) (BOURDIEU, 1979; 1998; BOURDIEU \& BOLTANSKI, 1998). Uma das possibilidades abertas pela análise da militância consiste justamente em considerar a atuação profissional em ONGs como resultado de "investimentos sociais múltiplos" e da participação anterior ou simultânea dos atores em um conjunto diversificado de "atividades sociais" (COLLOVALD, 2002; CORADINI, 2002; LECHIEN, 2002). Desse modo, a análise das modalidades de ocupação de cargos e de funções peritas em instâncias de proteção ambiental pode ser tomada como uma situação exemplar para a investigação das condições e das lógicas sociais de reconversão da formação escolar em competências profissionais. Isso porque, na situação em pauta, a militância ambientalista constitui um espaço de articulação de recursos diversificados para a ocupação de postos e de funções profissionais em diferentes esferas de atividade. Dessa forma, é possível colocar em questão e reconsiderar os limites, comumente aceitos, entre formação universitária, militância e exercício profissional.

O material utilizado como fonte de informação decorre de uma investigação sobre as condições e as lógicas sociais do engajamento e da participação na defesa de causas ambientais no Rio Grande do Sul entre 1970 e 2005 (OLIVEIRA, 2005). Em tal pesquisa foram realizadas 50 entrevistas biográficas com os dirigentes das principais ONGs ambientalistas do estado que ingressaram nas mesmas em diferentes momentos do período considerado, possibilitando a caracterização e a comparação de distintas gerações militantes. Tal 
material foi complementado pela realização de observações etnográficas da intervenção de tais dirigentes em uma série de eventos vinculados à defesa do meio ambiente (reuniões de associações, seminários e congressos, conselhos e comitês de proteção ambiental etc.). Os procedimentos metodológicos utilizados para o levantamento e a análise do referido material concentraram-se na investigação das trajetórias familiares, escolares, ocupacionais e militantes que os conduziram ao ambientalismo, no exame dos significados e das modalidades de uso da formação escolar associados à sua atuação e na análise da diversidade de esferas e de redes sociais que contribuem para a aquisição e a reconversão dos recursos que fundamentam suas concepções e práticas profissionais. O material obtido por meio de tais procedimentos conduziu à identificação de diferentes padrões de carreiras que conduzem à atuação profissional na "área do meio ambiente" no período considerado.

Com base em tais orientações teóricas e metodológicas, observou-se, primeiramente, que a forte incidência de dirigentes com formação universitária não parece conduzir-nos a uma militância caracterizada pela imposição de competências escolares e técnicas no âmbito da militância. Pelo contrário, muito mais do que a formação em si, o que importa é a sua vinculação com a "experiência vivida”, com a "realidade" e com a "prática". Assim sendo, o engajamento na defesa de causas ambientais é apresentado como uma forma de exercício profissional para tais dirigentes, pois aquilo que eles entendem por “profissão” já está desde o início impregnado por uma "conotação política", na medida em que se trata da realização de um "compromisso" com uma “realidade” que é sempre "política”. Nesse sentido, a politização apresenta-se como um dos traços constitutivos da própria definição e da prática profissional, na medida em que se trata de uma concepção "militante" da atividade profissional, segundo a qual a profissão está sempre associada ao engajamento e à participação política em diferentes esferas de atividade. É também com base nesse militância que se pode entender a participação na defesa ambiental como uma das vias de acesso para a atuação profissional nas mais diferentes esferas sociais. Assim sendo, pode-se dizer que tal militância constitui o fundamento principal da "paixão pela natureza” dos ambientalistas considerados. Por isso, o que predomina na ação dos dirigentes de ONGs ambientalistas é a persistência de uma visão da formação escolar e universitária como instrumento de intervenção política nas mais diversas esferas de atuação, de modo que o engajamento na defesa ambiental constitui simplesmente mais uma das formas de acesso à realização profissional em agências estatais, partidos políticos, universidades e centros de pesquisa, organizações profissionais etc.

Todavia, em meio à continuidade dessa concepção militante da escolarização e de sua vinculação com outros tipos de práticas profissionais e militantes, existem diferentes tipos de recursos e de vínculos sociais que possibilitam a utilização da formação escolar para a atuação profissional no ambientalismo. Tais diferenças não podem ser apreendidas como um resultado direto de suas concepções da escolarização, nem tampouco decorrem dos respectivos contextos políticos em que ocorre o engajamento. Elas evidenciam certas transformações quanto às condições e às lógicas sociais que conduzem os dirigentes à participação nesse tipo de causa, e mesmo que não resultem da ruptura em relação a essa perspectiva militante da profissão, sinalizam claramente para sua maior diversificação. Assim sendo, mesmo que a imbricação entre participação política e atuação profissional constitua um dos fundamentos principais da militância ambientalista, as modalidades por meio das quais ela ocorre são muito diversificadas, pois resultam de padrões distintos de combinação de títulos escolares com recursos e vínculos sociais estabelecidos com diferentes esferas sociais (familiar, de amizades, laboral, religiosa, política etc.). Com base no recorte geracional ${ }^{1} \mathrm{e}$ no exame das principais carreiras militantes ${ }^{2}$ a partir dos anos 1970, é

1 O termo "geração" é aqui utilizado no sentido de "comunidade de adesão” (FILLIEULE, 2005), pois diz respeito especificamente ao período de adesão dos dirigentes à militância ambientalista. Ele não implica necessariamente a existência de um "grupo marcado pelos mesmos acontecimentos políticos” (geração política), nem uma “comunidade de idade”. Sobre as diferentes dimensões implicadas no uso de tal termo, ver Sawicki (1997, p. 101, nota 85) e Fillieule (2001)

2 Sobre os problemas teóricos e metodológicos no uso da noção de "carreira” nas análises da militância ver, entre outros, Fillieule (2001; 2005), Agrikoliansky (2002), Collovald (2002), Siméant e Dauvin (2002) e Revue Française de Science Politique (2001). 
possível identificar diferentes padrões de engajamento no ambientalismo, bem como examinar suas relações com distintas modalidades de reconversão da formação escolar e universitária no âmbito da militância ambientalista ${ }^{3}$. Quanto a isso, as mobilizações desenvolvidas a partir de 1970 e, principalmente, nos anos 1980, têm uma importância destacada para a compreensão do processo de surgimento e de consolidação da problemática ambiental no caso do Brasil, na medida em que são representativas de um processo mais amplo de diversificação das modalidades de utilização da formação escolar e profissional como instrumento de politização em diferentes esferas de atuação.

Em consonância com isso, o texto está organizado em três partes principais. Em primeiro lugar, trata-se de demonstrar que a posição de dirigente ambientalista está respaldada em concepções e práticas referentes à formação e ao exercício profissional que supõem uma ligação estreita entre escolarização e militância política e que conduzem à utilização da formação escolar e universitária como instrumento de politização para a atuação profissional em diferentes esferas de atividade. Em um segundo momento, com base no exame das trajetórias sociais e dos itinerários escolares, militantes e ocupacionais dos dirigentes que ocupam cargos e funções perita em organizações ambientalistas, caracterizam-se os padrões de recursos e de vínculos sociais e políticos que fundamentam tal forma de exercício profissional, as diversidades de esferas e de redes sociais que conduzem ao ingresso e permanência no ambientalismo e os significados e as modalidades de uso da formação escolar associados a tal atuação. Tal análise evidenciou a existência de dois padrões principais de carreiras de dirigentes ambientalistas: de um lado, uma militância composta por líderes com origens sociais elevadas e cujas intervenções estão fundadas no cabedal cultural e político herdado ou construído a partir da família de origem; de outro lado, padrões de atuação que resultam do ingresso de indivíduos com origens sociais mais baixas e heterogêneas, que aderem ao ambientalismo durante a "juventude" em um momento anterior ou concomitante à entrada no Ensino Superior e no mercado de trabalho e que têm como principal base de recursos os vínculos estabelecidos no decorrer

\footnotetext{
3 Para maiores detalhes ver Oliveira (2005, cap. II, IV).
}

de seus itinerários familiar, escolar e profissional com partidos políticos, organizações e movimentos sociais diversificados. Para melhor visualizar tanto as diferenças principais entre tais formas de engajamento quanto sua heterogeneidade interna, tais padrões foram considerados em tópicos separados, enfatizando-se as diferentes modalidades que caracterizam cada uma deles.

\section{ESCOLARIZAÇÃO, ENGAJAMENTO POLÍ- TICO E CARREIRAS MILITANTES DOS DIRIGENTES ECOLOGISTAS}

As discussões sobre o papel e o lugar do "conhecimento científico", a utilidade das pesquisas e da "produção acadêmica", a relação entre "conhecimento" e "prática" etc., são temas bastante freqüentes no universo de pesquisa considerado. Tais assuntos aparecem em mesas redondas, oficinas, seminários, mas também nas reuniões de "entidades" e mesmo em conversas rotineiras entre militantes, em brincadeiras, confraternizações, durante as entrevistas etc. Para estes, o trabalho de pesquisa e, principalmente, a realização de entrevistas é algo muito comum, pois muitos estão empenhados em atividade semelhante ou já passaram por experiências como essas enquanto bolsistas de iniciação científica durante sua formação universitária, enquanto professores universitários ou no próprio exercício de suas atividades profissionais: nessas situações eles não estavam na condição de "objetos" de pesquisa e sim na de "sujeitos", como "pesquisadores" e "entrevistadores". Por isso, o acesso ao material, a permissão para participar de reuniões e eventos os mais diversos, bem como a disponibilidade para "dar uma entrevista", transcorrem em meio a "brincadeiras" e "cobranças" sobre a relevância da pesquisa para o movimento e a importância de haver um "retorno" do trabalho "para a sociedade", em contraposição à postura, que para eles é geralmente comum na "academia", do "pesquisador neutro", "irresponsável" e "descomprometido" com a "realidade" e com o movimento e que os trata simplesmente como "cobaias para testar suas teorias”.

Ao contrário das situações em que a competência técnica e a autoridade para falar em nome de uma causa supõem uma "tomada de distância do sujeito em relação ao objeto" (MEMMI, 1992), para os dirigentes ambientalistas é tal distanciamento que é visto com desconfiança e é até mesmo objeto de reprovação. Eles criticam 
a todo o momento o profissional e o pesquisador "neutros" e exigem o comprometimento e a responsabilidade da universidade e do "conhecimento científico" "perante a sociedade". Foram várias as situações durante a pesquisa em que tais cobranças vieram à tona: nas entrevistas, nas reuniões e até mesmo em conversas mais informais. Os dirigentes constantemente demandavam que o pesquisador estivesse comprometido com a causa ambiental e manifestavam publicamente certa descrença em relação à representação de "observador" do pesquisador. Um exemplo disso são as reuniões em que os coordenadores indagam ao pesquisador sua opinião sobre determinados assuntos que estão sendo discutidos; ou, ainda, quando perguntam publicamente se o pesquisador não planeja engajarse em nenhuma "entidade" após o término da pesquisa.

Nesse mesmo sentido, podem-se destacar certas conversas informais com os dirigentes em momentos anteriores a ou após reuniões e confraternizações. Um exemplo bem significativo disso foram alguns diálogos estabelecidos com uma das dirigentes da Associação Democrática Feminina Gaúcha - Amigos da Terra (ADFG-AT) em diferentes situações de pesquisa. Em uma reunião-almoço da Assembléia Permanente das Entidades de Defesa do Meio Ambiente do Rio Grande do Sul (Apedema-RS) (uma entidade de representação das organizações ambientalistas do estado), tal dirigente cobrou do pesquisador uma "militância" no sentido de ele "ter um compromisso com o movimento e de dar contribuições específicas quando for solicitado", citando como exemplo um professor do curso de Geografia da Universidade Federal do Rio Grande do Sul (UFRGS) que estabelece esse tipo de relação com a sua "entidade". Alguns meses depois, durante uma outra reunião com os representantes das ONGs estaduais no Conselho Estadual do Meio Ambiente (Consema), ela dirigiu-se ao pesquisador para contar-lhe que, após sua entrevista, ela deuse conta de que sabe muito pouco sobre a família de seu pai e que, como conviveu muito com sua avó materna, era da família da mãe que ela sabia mais. Por isso, quando foi a Florianópolis resolveu informar-se mais sobre a família de seu pai, por meio de conversas com ele bem como de vídeos e diapositivos que ele tinha. Concluiu dizendo que estava ansiosa para contar o ocorrido ao pesquisador porque isso demonstra o quanto 0 tipo de entrevistas realizado por ele "influencia" praticamente a própria "vida" das pessoas, no sentido de que as faz pensar sobre ela. Após isso, indagou novamente ao pesquisador sobre o seu engajamento. Por fim, tal cobrança aparece também durante as próprias situações de entrevistas. Um exemplo é a entrevista com o dirigente da União Protetora do Ambiente Natural (UPAN), durante a qual ele indagou ao entrevistador: "Não sei o que tu achas do nosso estatuto". Em seguida, completou em tom de brincadeira: "Opa! Tu é[s] impessoal! Tu só ouve[s]".

Essa exigência de uma "formação" "comprometida” com causas políticas e sociais constitui também um dos ingredientes principais de seus relatos sobre a formação escolar e universitária adquirida. Por um lado, a maioria apresenta a escola de maneira "negativa”; os motivos para isso são muito variados: sua falta de "utilidade prática”, a escola "pouco lhes deu”, eles tiveram que "descobrir quase tudo sozinhos" etc. Por outro lado, a descrição dos seus itinerários escolares destaca freqüentemente a importância de sua participação nos mais variados tipos de organizações e "movimentos sociais" para a compreensão da utilidade da formação escolar e universitária no exercício de suas atividades profissionais. Foi unicamente por meio do engajamento e da participação em diversos tipos de organizações e "movimentos sociais" (grêmios estudantis, diretórios e centros acadêmicos, organizações partidárias, o Movimento dos Trabalhadores Rurais Sem-Terra (MST), grupos de escoteiros, organizações religiosas, associações ecologistas etc.) que tais dirigentes conseguiram "entender a universidade" e o curso escolhido e que adquiriram os conhecimentos e os recursos técnicos que utilizam no exercício de sua profissão. Um bom exemplo dessa subordinação da formação escolar e universitária à militância estudantil e partidária é o caso de uma dirigente do Centro de Estudos Ambientais (CEA). Para ela, quando ingressou no curso de Educação Física, percebeu que a universidade "é a mesma coisa que [...] na escola" e foi somente por meio da militância estudantil que ela conseguiu "acompanhar a faculdade" e "entender o que se passava ali”. "É reprodução da escola. Tem os atletas que são os melhores alunos. [...] Aí, tem os ruins, que não sabem fazer nada; eu me incluía na classe dos ruins, que ficam ali, os excluídos da 
Educação Física. Uma coisa ridícula. A mesma coisa que é na escola. Eu fiquei apavorada. [...] E tu fica[s] excluído toda a faculdade. Daí, no segundo ano, mais pro final, duas colegas minhas entraram no movimento estudantil [...]. Daí, foi superlegal, porque eu consegui enxergar a faculdade... Bah, pra mim, foi tudo o Centro Acadêmico. Foi o que salvou a minha faculdade, senão teria sido um horror. Porque daí eu consegui, sabe, acompanhar a faculdade bem diferente. A minha atuação foi bem diferente... Consegui entender o que se passava ali. Foi por meio do movimento".

Tais formas de apresentação da "história pessoal” evidenciam que uma das motivações principais para o ingresso no ambientalismo é a idéia de que a aquisição de uma formação universitária, de competências técnicas e de suas vinculações com o exercício profissional é indissociável da capacidade de integrar tais tipos de conhecimentos a "ideologias e práticas políticas", de modo que, sem esse "compromisso" ou essa "articulação" com a "realidade” e com a "prática”, a escola e a formação que ela oferece não têm nenhum valor. Por isso, em contraponto às "limitações" encontradas na "escola formal", eles salientam a grande importância que adquiriu em seus itinerários escolares e profissionais um conjunto diversificado de "vivências", de modos de "sociabilidade", de engajamentos e militâncias, demonstrando que foi "fora da escola" e da "universidade" que se estabeleceram o valor e a utilidade de sua formação profissional. Para tais dirigentes, a formação escolar e técnica é algo que só tem utilidade se estiver associada a uma "prática”, à “experiência vivenciada” pela participação na "realidade" e, mais especificamente, em organizações políticas e nos “movimentos sociais". É com base nisso que avaliam a utilidade da formação escolar e universitária e que apresentam a "escola" como algo que pouco contribuiu para sua formação profissional (OLIVEIRA, 2005; 2007).

Dessa forma, em vez de fundamentarem-se na imposição da técnica e das competências peritas, as definições que respaldam suas intervenções militantes estão baseadas em concepções militantes da formação profissional, no sentido de que ela resulta da capacidade de submeter a formação escolar e universitária ao engajamento e à participação política em diversos tipos de organizações e de "movimentos sociais".
Por isso, independentemente do tipo da formação universitária adquirida (Educação Física, Biologia, Geologia, Direito, Ciências Sociais, Jornalismo etc.), é essa militância a respeito da escolarização e da atividade profissional que constituem a tônica principal do relato dos entrevistados e que delimitam suas perspectivas de inserção e de ocupação de postos no mercado profissional. Nesse sentido, pode-se dizer que, para o conjunto dos dirigentes, o engajamento e a participação política constituem um dos ingredientes principais de sua formação e do seu exercício profissional e não algo que é simplesmente "complementar" ou "adicional" ao seu trabalho e à sua ocupação. Diante disso, a participação no ambientalismo é sempre apresentada como uma forma de extensão ou prolongamento "natural” de sua formação escolar e profissional, devendo ser caracterizada, nas palavras dos próprios entrevistados, como uma “área de atuação profissional” e não como uma atividade "externa" ao desempenho de suas ocupações profissionais.

O levantamento de informações sobre a idade de entrada no ambientalismo mostrou que a grande maioria dos que atuam em organizações ambientalistas ingressou nesse tipo de militância muito antes dos 30 anos, período que corresponde ao tempo da formação e do ingresso no mercado profissional. Quando se observam as principais faixas etárias relativas ao período de entrada no ambientalismo, percebe-se claramente que o período do seu engajamento acontece predominantemente durante a "juventude" ou, mais precisamente, entre o momento de conclusão do Ensino Médio e o tempo de entrada em e de desenvolvimento da formação universitária. Como comprovação disso, verifica-se que quase a metade dos entrevistados (40,8\%) aderiu ao ambientalismo até os 23 anos de idade e que outra parcela significativa $(20,4 \%)$ ingressou na faixa dos 24 aos 29 anos.

A predominância do ingresso em organizações ambientalistas nessas faixas etárias é significativa do quanto esse tipo de engajamento ocorre em um momento de escolha e de formação profissional. O que se reforça, primeiramente, pelo fato de que a idade média de ingresso dos entrevistados na universidade é de 21 anos e a de conclusão, de 26 anos. Assim, de um total de 42 entrevistados para os quais se dispõe dessa informação, observa-se que a sua grande maioria $(83,3 \%)$ ingressou na universidade até os 23 anos 
e o restante, a partir dos 24. Já no que diz respeito aos que aderiram à defesa ambiental em uma fase mais tardia de sua formação e do seu exercício profissional, relativamente mais próxima à retração de suas atividades no mercado de trabalho, os percentuais são bem inferiores: eram $14,3 \%$ os que estavam com idades entre 30 e 39 anos, 16,3\% os que ingressaram no ambientalismo entre 40 e 49 anos, enquanto em apenas quatro casos, que equivalem a um percentual de $8,2 \%$, ocorreu a entrada no ambientalismo em uma idade que coincide com ou aproxima-se do momento de aposentadoria. Em somente um caso, a entrevistada ingressou após ter-se aposentado. Em segundo lugar, quando se considera o período que vai do início da década de 1970 ao começo dos anos 2000, constata-se que tem havido uma forte tendência de diminuição da faixa etária de entrada no ambientalismo. O momento de início desse engajamento sinaliza nitidamente, e cada vez mais, o recrutamento de indivíduos cuja faixa etária coincide com a idade de entrada e de desenvolvimento da formação universitária e do exercício profissional. É nas faixas etárias em que há maior investimento em termos de formação e de procura de espaço no mercado de trabalho que a grande maioria iniciou sua participação na defesa de causas ambientais. Dito de outro modo, é em uma fase decisiva de seus itinerários escolares e profissionais que os militantes ambientalistas, como eles mesmos costumam dizer nas entrevistas, foram "despertados" para a defesa do meio ambiente.

Além disso, essa estreito vínculo da formação com o engajamento não ocorre apenas no período universitário inicial. Observa-se, por um lado, que a participação em diversos tipos de organizações e de "movimentos sociais", antes de entrar no ambientalismo, é muito grande entre os entrevistados. São raros os casos daqueles que aderiram ao ambientalismo sem experiências anteriores em organizações políticas as mais diversas, como organizações estudantis (grêmios, centros e diretórios acadêmicos), sindicatos, partidos políticos, organizações religiosas e assistenciais etc. Somente três entrevistados (6,1\%) não apresentaram algum tipo de vinculação anterior com organizações desse tipo. Já os que apresentaram alguma forma de envolvimento com organizações como essas, como simpatizantes ou militantes, constituem a grande maioria, perfazendo 93,9\%. Desse modo, percebe-se que, em geral, entre a socialização política no meio familiar e a adesão a organizações ambientalistas, encontra-se um conjunto muito diversificado de participações, desligamentos e novas adesões a outros tipos de organizações e "movimentos sociais”. Nesse sentido, poder-se-ia dizer que em matéria de experiências políticas os ambientalistas raramente chegam "verdes" na defesa ambiental, como muito bem enunciou um dos entrevistados. Por outro lado, no que diz respeito ao tempo de permanência em organizações ambientalistas, observa-se que a militância ambientalista tem um tempo de duração relativamente longo. Mesmo que se caracterize como uma militância que ocorre na “juventude”, a participação na defesa de causas ambientais é uma característica constante também no período de exercício profissional e não deve ser assimilada a uma "fase" passageira que ocorre apenas no período inicial de seu itinerário escolar e profissional. Quanto a isso, vale mencionar que em quase todos os casos considerados, as "pósgraduações”, os cursos realizados ou direcionamento do exercício profissional estão voltados para a "área de meio ambiente".

Tais aspectos colocam-nos diante de uma situação bastante diferenciada daqueles casos em que o ingresso e a participação associativa ocorrem em uma fase relativamente tardia da formação escolar e do exercício profissional, ou, mais precisamente, quando os indivíduos estão próximos do período de aposentadoria (PASSY, 1998; AGRIKOLIANSKY, 2002). Assim sendo, é a estreita ligação entre os itinerários escolares, militantes e profissionais que se apresenta como uma das características decisivas da atuação na "área de meio ambiente" e não a maior disponibilidade gerada pelo distanciamento dos indivíduos em relação às suas funções e atividades no mercado de trabalho (sob a forma de aposentadoria ou mesmo do desemprego). Por outro lado, tal situação difere também da que é encontrada nas abordagens que apresentam o engajamento ambientalista como consistindo na utilização de "competências peritas", adquiridas por meio da formação e do exercício profissional, como instrumento de intervenção militante (OLLITRAULT, 2001, p. 126). Na situação em pauta, a imbricação do engajamento com o exercício profissional não resulta de uma espécie de imposição dessas competências técnicas como os principais recursos militantes, nem tampouco de um “diletantismo profissional” (SIMÉANT, 
2001; SIMÉANT \& DAUVIN, 2002), pois os significados atribuídos ao engajamento e à profissão têm conotações bem diferenciadas. Trata-se de uma situação em que o "sentido" e o valor da profissão implicam sempre um “compromisso" com uma "realidade" que é "totalmente política”, de modo que a formação e o exercício profissional não existem separados da capacidade ou da competência de "comprometimento" da formação escolar e técnica com a "realidade" e com a "prática”, ou no caso, com a "natureza” e com a "vida”. É por isso que o engajamento, mais do que significar "pôr-se acima da profissão", constitui sempre uma forma de realização profissional, de não distanciamento da "realidade".

Essa concepção de política como uma "missão" e como um "compromisso com a realidade" constitui um dos fundamentos principais da definição e do exercício "militante" da profissão, possibilitando que o ajuste entre a formação escolar e o engajamento não se apresente como algo conflituoso para os próprios dirigentes. No entanto, não estamos diante de concepções de sociedade e de política e de perspectivas militantes da formação e do exercício profissionais que sejam próprias dos atores que participam da defesa de causas ambientais. Pelo contrário, os princípios que fundamentam essas concepções e práticas estão vinculados à própria configuração do espaço escolar e do exercício profissional no Brasil (CORADINI, 1998; DEZALAY \& GARTH, 2002; CONNIFF, 2006; LOVE \& BARICKMAN, 2006). Esses princípios fundamentam, por um lado, concepções e práticas que fazem do engajamento e da participação política uma forma de extrapolar os "limites de sua profissão" e de associar sua formação escolar e o exercício profissional à "cultura geral” e ao "humanismo" (Coradini, 1998) e, assim, "pôr-se acima do simples exercício de sua profissão" (DEZALAY \& GARTH, 2002); por outro lado, constituem também um dos ingredientes principais das mais diferentes formas de militância (CORADINI, 2002). Trata-se, enfim, de uma situação em que o sentido e o valor da "profissão" são inseparáveis do "compromisso" com uma "realidade" que é "totalmente política" (PÉCAUT, 1990), de modo que a formação escolar e o exercício profissional requerem a capacidade ou competência de "comprometimento" da formação escolar e técnica com "a realidade" e com a "prática" ou, no caso, com a "natureza" e com a "vida". É por isso que o engajamento e a militância política, mais do que significar "ruptura" ou "distanciamento" das atividades profissionais, constitui sempre uma forma de "realização profissional", de "comprometimento" e de não distanciamento da "realidade". Nesse sentido, poder-se dizer que a atuação no ambientalismo constitui uma forma de "ruptura" com o "simples" exercício profissional e de reativação de disposições que possibilitem "extrapolar os limites da profissão”, uma vez que, para eles, quando a formação e o exercício da profissão estão minimamente dissociados da "prática”, resultam na "limitação" e na "redução" das possibilidades de seu desempenho e atuação.

Dessa forma, as definições que respaldam a atuação dos dirigentes remetem-nos para concepções militantes da formação e do exercício profissional, no sentido de que eles são constituídos acima de tudo pela capacidade de submeter a formação escolar e universitária ao engajamento e à participação política em diversos tipos de organizações e de "movimentos sociais". É com base nessa concepção militante da formação e do exercício profissional que os dirigentes ambientalistas olham com suspeição e desconfiança quem demonstra certa distância em relação à "natureza" ou à participação em organizações políticas e "movimentos sociais", seja durante a infância, seja no transcorrer do seu processo de escolarização e de exercício profissional. Por isso, não podemos simplesmente considerar a preponderância de dirigentes com formação escolar elevada como sinônimo de "profissionalização" do ambientalismo ou como um resultado direto disso, como tem sido feito por parte da literatura nacional e internacional. Primeiramente, porque no caso em pauta não existe um conjunto determinado de formação universitária e de diplomas que sejam mais favoráveis à entrada e à hierarquização das posições de direção na defesa do meio ambiente. Antes disso, é preciso dar conta dos significados e concepções atribuídos à formação escolar e universitária, como também dos tipos de recursos que fundamentam essa modalidade de atuação e dos respectivos espaços e vínculos sociais a partir dos quais são adquiridos.

Nesse sentido, pode-se dizer que essa estreita ligação da escolarização com a militância na defesa de causas ambientais é representativa de um processo mais amplo de diversificação das 
modalidades de utilização da formação escolar e profissional como instrumento de politização em diferentes esferas de atividade, o qual está relacionado a mudanças ocorridas tanto nas dinâmicas próprias da militância e da participação política quanto no espaço da formação e do exercício profissionais. Dentre os fatores que propiciaram isso, destacam-se, em primeiro lugar, certas mudanças nos contextos político e ideológico dos anos 1980. É o caso da abertura dos espaços de participação política decorrente do "processo de redemocratização" que resultou na intensificação do "fenômeno da militância múltipla”, de modo que as redes de lideranças de diferentes organizações e movimentos sociais tornaram-se extremamente interligadas (MISCHE, 1997). Em segundo lugar, encontram-se mudanças no espaço da formação escolar e profissional; trata-se, mais especificamente, da expansão e da diversificação do Ensino Superior, que propiciou a ampliação dos usos instrumentais da escolarização e da formação profissional com vistas à politização e à articulação de diferentes esferas de atuação, por meio da inserção e da militância anterior e/ou simultânea em diversos tipos de organizações e movimentos sociais (CORADINI, 2002). Por fim, destacam-se certas transformações das próprias bases sociais e das dinâmicas de ingresso na militância ambientalista. Desse modo, observa-se que nos anos de 1980 ocorreu uma passagem da militância composto por líderes com origens sociais elevadas e cujas intervenções estavam fundadas na bagagem cultural e política herdada ou construída a partir da família de origem, para padrões de atuação que resultam do ingresso de indivíduos com origens sociais mais baixas e heterogêneas e que têm como principais bases de recursos os vínculos estabelecidos no decorrer de seus itinerários familiar, escolar e profissional com partidos políticos, organizações e movimentos sociais diversificados (OLIVEIRA, 2005).

Um dos procedimentos pertinentes à apreensão dessa modificação nos tipos de recursos e de vínculos que conduzem à atuação profissional em ONGs é o exame dos principais padrões de carreiras que conduzem à ocupação de cargos e funções profissionais como "ambientalistas" em diferentes esferas sociais. O uso da noção de "carreira” na análise do militância procura dar conta, por um lado, das disposições favoráveis à participação política e de suas relações com as desigualdades de condições de origem e os respectivos capitais (social, econômico, político e cultural) possuídos pelos diferentes agentes sociais (BOURDIEU, 1979; 1980) e, por outro lado, dos pertencimentos múltiplos dos atores sociais e dos diversos contextos e situações relacionados aos processos de socialização que resultam na constituição e na modificação das disposições que conduzem à participação em mobilizações coletivas (FILLIEULE, 2001). Tratase, portanto, de integrar a perspectiva diacrônica na investigação dos processos de socialização que conduzem à atuação profissional em ONGs ambientalistas e de apreender os padrões de entrelaçamento de diferentes "ordens de experiência” (familiar, escolar, militante e profissional) vinculadas a esse tipo de atuação. Dessa forma, tal análise contribui para a compreensão do exercício profissional nas organizações e nas instâncias de proteção ambiental como resultado de "investimentos sociais múltiplos”; essa compreensão leva-nos a investigar as disposições associadas à atuação individual como conseqüência da intersecção entre os processos de socialização vinculados, por um lado, às suas condições de origem e trajetórias familiares e, por outro lado, aos que decorrem das experiências e dos diversos contextos interacionais interligados à biografia individual; ou, mais precisamente, à multiplicidade de esferas e de redes sociais associadas ao seu engajamento e à sua participação anterior ou simultânea em um conjunto diversificado de atividades, organizações e movimentos sociais.

A caracterização dos principais padrões de carreiras que conduzem à ocupação de posições dirigentes em ONGs ambientalistas entre os anos 1970 e 2000 possibilita evidenciar a diversificação das modalidades de utilização instrumental da formação escolar para a politização de diferentes esferas de atividade e suas relações com disposições e recursos acumulados por meio de vínculos estabelecidos em diversos espaços sociais no decorrer dos percursos biográficos dos atores. Em vez de tomar a inserção profissional como um resultado direto de um mercado de trabalho abstrato, trata-se de demonstrar que são as disposições e os recursos adquiridos no universo da família de origem e nos itinerários escolares, militantes e profissionais dos respectivos atores que delimitam diferentes possibilidades de exercício de funções peritas na defesa ambiental. 
Assim sendo, a maior predominância do ingresso no ambientalismo em plena fase formativa - universitária e profissional - está estreitamente ligada ao surgimento de novas modalidades de articulação da formação escolar com o engajamento político em diversas esferas de atuação, decorrente tanto do processo de expansão da escolarização no Brasil quanto de sua correspondência com uma grande proliferação de organizações e "movimentos sociais" vinculados às mobilizações pela “democratização”. Em conformidade com isso, a adesão a organizações e a mobilizações vinculadas à defesa de causas ambientais a partir desse período resultou na configuração da defesa do meio ambiente como um militância de reconversão de diferentes tipos de formação escolar e universitária para a atuação profissional em diversas esferas de atividade: estatal, partidária, associativa, acadêmica, religiosa etc. Atualmente, a inserção anterior e simultânea em diversas redes de organizações e de "movimentos sociais" constitui um dos condicionantes principais da reconversão da formação escolar para ingresso, permanência e ocupação de postos nas organizações e instâncias que atuam na defesa de causas ambientais. A maior imbricação do engajamento político com a formação escolar e universitária não ocorre apenas no momento de adesão ao ambientalismo ou posterior à entrada nas organizações ambientalistas. Ela resulta de processos de socialização política nos âmbitos familiar e escolar, da participação anterior em organizações e "movimentos sociais" os mais diversos (estudantil, sindical, partidário, religioso, entre outros), estando também relacionada a trajetos sociais, políticos e profissionais diferenciados.

\section{III. “BOA EDUCAÇÃO”, NOTABILIDADE PRO- FISSIONAL E ATUAÇÃO EM ONGS}

Com inúmeras diferenças entre os casos analisados, o padrão de atuação profissional no ambientalismo que tem início nos anos de 1970 pode ser caracterizado pela predominância dos recursos e vínculos associados à bagagem cultural e política herdada ou construída a partir da família de origem (OLIVEIRA, 2005). De maneira geral, tratam-se de indivíduos com origens sociais elevadas: a grande maioria é filha de grandes comerciantes, estancieiros, juízes, profissionais liberais (como advogados e engenheiros) e oficiais militares com formação universitária. Como bem definiu um dos dirigentes entrevistados, todos eles tiveram “toda a formação da boa sociedade”, "boas escolas”, formação superior. Suas famílias "viviam no mesmo meio", sendo que muitos deles já se conheciam antes de aderirem à causa ambiental em função dessa convivência, por freqüentarem os mesmos clubes e pelos laços de vizinhança ou de amizade há muito estabelecido entre eles.

O fato de tratarem-se de dirigentes recrutadas em famílias de posição elevada e vinculadas às elites dirigentes do "regime autoritário" era uma das condições que possibilitava a redução dos custos que a participação em mobilizações políticas poderia acarretar para os indivíduos durante o "regime militar”. A posição social de origem dos ambientalistas "fundadores" foi um dos fatores que possibilitaram o seu engajamento, na medida em que colocava tais indivíduos diante de um conjunto de situações e de experiências que contribuíram para a formação de certas disposições ligadas à participação na defesa de causas ambientais naquele momento. Os vínculos de parentesco e de amizade com o universo das elites políticas, religiosas, militares e empresariais são alguns dos principais ingredientes da socialização familiar de tais líderes e constituem alguns dos fatores que estão na origem das disposições políticas que os conduziram à defesa de causas ambientais. Além disso, a origem estrangeira do grupo familiar, as viagens e os contatos freqüentes com organizações e pessoas em outros países estão na origem de seu cosmopolitismo e de suas propensões a aderir a problemáticas políticas e ideológicas que estão acima das divisões e fronteiras nacionais (LOUREIRO \& PACHECO, 1995, p. 149). Juntese a isso o fato de os tipos de engajamentos que antecedem seu ingresso no ambientalismo consistirem na freqüência a clubes e a eventos culturais, a grupos naturistas e a organizações assistencialistas.

Tais aspectos estão na origem de um padrão de participação no ambientalismo baseado fundamentalmente na bagagem cultural e política herdada do grupo familiar de origem e resulta em uma concepção de participação política fundada nas relações estabelecidas a partir da esfera familiar. Tratam-se de modalidades de inserção e de concepções de política “particularística” e "aristocrática” (CORADINI, 1998), fundadas no “dom” e na "opinião pessoal” decorrente de sua elevada condição social (BOURDIEU, 1979) e não de formas de participação que pressupõem a 
aquisição de recursos militantes mediante a filiação ou a militância anterior em organizações políticas, partidárias e "movimentos sociais". Quando isso ocorre, os recursos militantes adquiridos mediante a participação em associações ambientalistas representam um "fim suplementar" que lhes permite "maximizar outros bens raros" que tais dirigentes possuem (GAXIE \& OFFERLÉ, 1985, p. 111). Isso conduz a concepções e práticas que remetem sua atuação na "área de meio ambiente" à esfera da "ética", da "filosofia” e dos "valores morais”. Nesse sentido, a grande maioria iniciou sua participação em associações ambientalistas com faixas etárias elevadas, em uma fase mais tardia da formação universitária e profissional e em um período próximo ao momento da aposentadoria. Mesmo assim, pode-se falar de uma militância de reconversão profissional, na medida em que tal engajamento está diretamente associado à retomada e à reorientação da carreira e do exercício profissional. A participação em mobilizações e organizações ambientalistas constitui uma forma de aquisição de posições de notabilidade com base na bagagem cultural e familiar, mesmo para aqueles que não exerciam atividades profissionais ou que tiveram que as recusar em virtude da vida familiar. Pode-se, portanto, distinguir algumas modalidades principais de adesão ao ambientalismo entre tais dirigentes: de um lado, aqueles cujo engajamento constitui uma forma de retomada de uma "carreira profissional” interrompida; de outro lado, os que buscam na defesa ambiental uma forma de reorientação de seu exercício profissional.

Em primeiro lugar, tratam-se de modalidades de participação constituídas pelas esposas de empresários, médicos e juízes que haviam abandonado suas atividades e carreiras profissionais em função do casamento e da criação dos filhos. Dotadas de uma elevada bagagem cultural e escolar, no sentido que Saint-Martin (1999) chama de capital de "boa educação”, elas adquiriram o aprendizado do voluntariado na família e na escola e, muito antes de atuarem no ambientalismo, apresentam um itinerário de dedicação a atividades voluntárias, religiosas e caridosas. É como desdobramento da formação adquirida no meio familiar e escolar e desenvolvida por meio do trabalho voluntário que ocorre o ingresso na defesa do meio ambiente. Nesses casos, a atuação no trabalho voluntário e, posteriormente, no ambientalismo possibilita a “recuperação” ou a "retomada” de uma carreira escolar e profissional interrompida ou mesmo abandonada. Em decorrência da grande disponibilidade de tempo gerada pela ausência da necessidade de trabalhar, puderam dedicar-se integralmente às organizações, tornando-se verdadeiras "funcionárias" em um momento em que, segundo elas próprias, a "ecologia” não era algo "muitíssimo sério” como é atualmente, pois consistia, basicamente, em uma "ocupação para pessoas que tinham tempo a dedicar”. Com base em tais condições e nos recursos proporcionados pela família de origem, elas adquiriram uma notoriedade tanto no âmbito nacional quanto internacional, conseguindo estabelecer parcerias e vínculos financeiros com empresas, organizações estatais, bem como com fundações e organismos internacionais.

Pode-se citar como trajeto típico de tal modalidade o caso da Presidente de Honra da Associação Democrática Feminina Gaúcha Amigos da Terra (ADFG-AT). Seu pai era alemão e trabalhava como comerciante de importação, conseguindo dar continuidade ao seu trabalho durante a II Guerra Mundial devido às "ótimas amizades” e, principalmente, às relações de amizade estabelecidas com o dono do principal jornal do Rio Grande do Sul, Breno Caldas. Ela ingressou na associação quando estava com 40 anos, era casada com um grande empresário gaúcho, tinha três filhos e já concluíra havia bastante tempo sua formação universitária: tem mestrado em Línguas Anglo-Germânicas, sendo também formada em didática na UFRGS e em Língua e Literatura Francesas pela Aliança Francesa de Porto Alegre. Todavia, teve que interromper os estudos, recusando, primeiramente, uma bolsa para estudar um ano nos EUA em decorrência da proibição do pai e, posteriormente, em função do casamento e da criação dos filhos. Antes mesmo de ingressar na entidade, já fazia o que chamou de "intervenção social”, que consistia em fazer "bordadinhos”, doados à Igreja Católica para "ajudar os pobres”. Na referida associação seu trabalho esteve inicialmente voltado para a “ação social”: participação em cursos de assistência social na própria organização, em clubes de mães, colégios, creches etc. Entretanto, foi quando o trabalho da associação voltou-se para a temática ambiental que ela pôde retomar seus antigos anseios de atuação no âmbito internacional e, com base em uma grande disponibilidade 
profissional e, principalmente, na notoriedade e no prestígio decorrentes dos vínculos familiares, conseguiu a articulação do trabalho desenvolvido pela associação com organizações ambientalistas, organismos e fundações nacionais e internacionais. Desse modo, tornou-se uma das principais articuladoras da aproximação entre a ADFG e as mobilizações ambientalistas e, mais tarde, da integração de tal organização à Federação Internacional Amigos da Terra.

Em segundo lugar, destacam-se as modalidades de participação representadas pelos que foram denominados de "profissionais liberais". Diferentemente do caso anterior, tratam-se de indivíduos que tinham uma razoável situação profissional e ocupacional como executivos de grandes empresas multinacionais (Basf, Citibank) ou como funcionários do setor público (da Justiça Federal, da UFRGS, do Ministério da Agricultura). Seus engajamentos também ocorreram em faixa etária elevada, mas eles combinaram-se com uma fase mais tardia do exercício profissional, relativamente próxima ao momento de aposentadoria. Todavia, além da bagagem cultural propiciada pela sua origem social elevada, tais dirigentes podiam contar também com a "notoriedade" e os vínculos estabelecidos por meio do exercício profissional. A adesão ao ambientalismo funcionou como uma forma de reorientação de suas atividades e do próprio exercício profissional. Em alguns casos, tal redefinição profissional constituiu uma forma de retomada de certas aspirações descartadas no decorrer de seus itinerários escolares e profissionais. Todavia, uma das características predominantes nesse conjunto é a articulação da bagagem cultural adquirida por meio da família de origem com certa "notabilidade” e prestígio vinculados à formação e ao exercício profissional como instrumentos de intervenção em diferentes esferas de atuação.

Um dos exemplos mais representativos dessa modalidade de atuação profissional é o do primeiro Presidente da Associação Gaúcha de Proteção ao Ambiente Natural (Agapan) (DREYER, 2004). Um dos principais aspectos que chama a atenção no referido caso e que o torna extremamente significativo quanto às modalidades de reconversão profissional dos ambientalistas da década de 1970 e até mesmo dos dirigentes das gerações posteriores é, justamente, a diversidade de esferas que, com sua atuação, passaram a ser vinculadas à defesa ambiental. Essa combinação de atuação diversificada corresponde também ao seu reconhecimento simultâneo com um conjunto bastante heterogêneo de qualidades, como "cientista”, "professor”, "agrônomo", "ecologista" etc. Ele era filho de um arquiteto bem-sucedido que se tornou mais tarde pintor e professor do Instituto de Belas Artes da UFRGS e de uma "fervorosa liderança da comunidade católica" que pertencia a uma das famílias de maior influência política e econômica no Rio Grande do Sul. Formou-se em Agronomia pela UFRGS e, logo em seguida, conseguiu uma bolsa de estudos na Lousiana State Universty, nos Estados Unidos, onde realizou um curso de pós-graduação em Estudos do Solo e Agroquímica. Após trabalhar durante sete anos na Companhia Riograndense de Adubos e, depois, na Sulpampa (que era do mesmo ramo), foi contratado para trabalhar com fertilizantes como um alto executivo da multinacional Basf - a mesma empresa em que trabalhava seu sogro. Em função desse novo emprego ficou fora do país como executivo da empresa durante 13 anos: dois na Alemanha, sete na Venezuela e quatro no Marrocos. Seu ingresso no ambientalismo ocorreu quando ele estava com 45 anos e teve como marco seu pedido de demissão da Basf, segundo ele próprio, para "mudar o rumo de sua vida". Quando isso ocorreu, ele já tinha aderido ao naturismo, estabelecido contato com algumas associações e com lideranças vinculadas ao "ecologismo", na Europa e nos Estados Unidos, chegando a entrar em contato com algumas "entidades de luta”, como ele mesmo definiu, que eram a Adubon Society ou o Sierra Clube, que o inspiraram na criação da Agapan. Sua "experiência internacional" foi decisiva para a ocupação do cargo de Presidente da referida associação. A partir daí, entregou-se totalmente ao "trabalho de proteção ambiental", a ponto de tornar-se um "ativista em tempo integral” e, com base na visibilidade, na projeção e nos vínculos alcançados no âmbito nacional e internacional, conseguiu articular de maneira exemplar e duradoura o ativismo ambiental com a atuação profissional em associações ambientalistas, organizações profissionais, empresas, administrações e organismos públicos, nas áreas de manejo e de reciclagem de resíduos, paisagismo, urbanismo e saneamento natural etc. (idem).

A predominância em tal padrão de participação da "geração" que ingressou nos anos de 1970 não 
implica que o cabedal político e cultural do grupo familiar tenha, atualmente, deixado de exercer uma importância destacada sobre o ingresso e o desenvolvimento da atuação profissional na defesa ambiental. São muito comuns os casos em que a adesão a campanhas e o ingresso em organizações ambientalistas ocorreu com base nos vínculos estabelecidos a partir do cabedal político e cultural da família de origem. Uma variante disso são as situações em que os filhos ou parentes de dirigentes "pioneiros" ingressaram em associações e organismos públicos de proteção ambiental com base nos recursos decorrentes da militância ambientalista do pai ou da mãe (OLIVEIRA, 2005, p. 251-256).

Como representante dos padrões de carreiras de dirigentes ambientalistas que se caracterizam pela existência de itinerários cuja reconversão da formação escolar contou com recursos e vínculos estabelecidos, basicamente, por meio da família de origem, pode-se destacar o caso da atual Presidenta da Fundação Gaia. Trata-se de um itinerário militante diretamente vinculado ao cabedal cultural e político adquirido no meio familiar e, principalmente, às redes de relações construídas a partir da atuação profissional de seu pai na defesa ambiental. O contato com organizações e dirigentes que participavam da defesa do meio ambiente ocorreu desde a infância no próprio meio familiar, pois sua casa estava sempre repleta de militantes ambientalistas em decorrência da atuação de seu pai, além de ser também um local onde aconteciam reuniões e conversas informais com os dirigentes das principais organizações ambientalistas do Rio Grande do Sul e até mesmo de outras regiões do país. Seu itinerário universitário sempre esteve diretamente associado à atuação de seu pai na defesa do meio ambiente, de modo que, ao concluir o Ensino Médio e ingressar no Ensino Superior, começou a acompanhá-lo em suas viagens internacionais, "atuando como secretária dele" durante todo o seu percurso na universidade. Em decorrência disso, levou seis anos para concluir o curso de licenciatura em Biologia, que, segundo ela própria, pode ser "feito tranqüilamente em quatro anos”. Esse itinerário de intensa militância não possibilitava o acompanhamento das aulas, tornando-se, segundo ela mesma, uma espécie de "visitante na faculdade". Mesmo assim, afirma que não se "sentia diferente dos colegas", destacando que o curso de Biologia era "muito fragmentado e dissociado do contexto", tornandose mais interessante somente no final, quando começou a fazer cadeiras de Ecologia. Desse modo, afirma que foram poucas as coisas que aprendeu por meio de sua formação universitária e conclui: "Aprendi muito mais com meu pai, não tenha dúvida”. O mesmo ocorre com seu itinerário profissional, que começou e desenvolveu-se sempre associado à atuação do pai. Por meio das relações deste com organizações ambientalistas internacionais, quando ainda estava cursando Biologia na universidade, conseguiu um estágio em uma "ONG da Alemanha" em função de tê-lo acompanhado em um ciclo de palestras que ele fez na Europa; no final da graduação, começou a trabalhar integralmente na organização fundada e presidida pelo pai, passando a supervisionar e a coordenar todos os diferentes projetos e trabalhos dentro da Fundação Gaia, assumindo um pouco antes de ele falecer a posição de Presidenta da referida fundação. Dessa forma, sua atuação sempre foi nas empresas do pai, chegando mesmo a afirmar: "nunca trabalhei em outro lugar". Também os contatos que estabeleceu na Europa e nos Estados Unidos foram resultado de sua “atuação internacional” desde a adolescência, quando "trabalhava" com o seu pai. Dessa carreira profissional diretamente vinculada à atuação do pai, tanto no âmbito local como nos nacional e internacional, resultou uma forte articulação do trabalho desenvolvido pela organização com a esfera internacional. Tal itinerário conduz à concepção da atuação profissional como diretamente associada com questões éticas e filosóficas, estando respaldada em princípios que fazem da atuação profissional algo diretamente subordinado ao cabedal cultural, ao conjunto de experiências e aos valores éticos que suscita. Assim, ela salienta que a formação escolar e universitária não é algo que considere fundamental para a atuação na defesa do meio ambiente. Mesmo em se tratando de sua área - pois, segundo ela, “o biólogo é naturalmente o profissional que mais tem a ver com ecologia, que mais se aprofunda na questão da ecologia dentre as diversas áreas profissionais” -, a formação escolar não é uma condição necessária ou fundamental. Anterior à formação universitária apresenta-se a "educação” adquirida por meio do "berço familiar”, das "diferentes experiências [por] que tu passaste na vida" e das "crenças que tu vais acumulando nesse processo". 


\section{FORMAÇÃO SUPERIOR, MILITÂNCIA} MÚLTIPLA E INSERÇÃO PROFISSIONAL

A partir da segunda metade da década de 1980 houve uma acentuada diversificação das modalidades de atuação profissional na "área de meio ambiente”. Trata-se de um padrão de atuação que se caracteriza pela intensificação da imbricação entre a formação universitária e a militância política em organizações e movimentos sociais diversificados. Tais características dão origem a concepções e práticas que vinculam a atuação na “área do meio ambiente” à esfera da militância em partidos políticos, em administrações públicas e na burocracia estatal, em sindicatos e associações profissionais, em organizações religiosas e em movimentos populares. Em decorrência disso, as modalidades de carreiras de ambientalistas a partir desse período são extremamente diversificadas, assim como as lógicas sociais postas em confronto nesse tipo de atuação profissional. Mesmo assim, é possível diferenciar alguns padrões principais e examinar suas relações e especificidades com os itinerários familiares, escolares, militantes e profissionais que conduzem à ocupação de cargos profissionais na defesa ambiental.

Em que pese a diversidade de esferas sociais associadas à atuação profissional na defesa de causas ambientais e dos vínculos sociais e políticos em que se baseia, pode-se identificar algumas regularidades quanto às condições e lógicas sociais que conduzem a essa forma de exercício profissional pela descrição de alguns dos principais padrões de carreiras de ambientalista. Uma das principais características das carreiras desse período é que a atuação em ONGs conduz a dinâmicas de reconversão profissional com base nos vínculos estabelecidos a partir da intenso militância em organizações estudantis, partidárias e movimentos sociais diversificados. Na maioria dos casos tal articulação conduz à ocupação de cargos e funções remuneradas na administração pública e na burocracia estatal com base nos vínculos estabelecidos na militância partidária. Em outros casos, ela direciona-se seja para o exercício de assessoria e consultoria "na área de meio ambiente", seja para a atuação no interior da "profissão" em assuntos vinculados ao exercício de determinadas categorias profissionais (Jornalismo, Direito, Biologia etc.), ou, ainda, ao desempenho de funções remuneradas como funcionários e técnicos de ONGs (OLIVEIRA, 2005, p. 256-308).
Desse modo, dentre os inúmeros padrões de reconversão profissional por meio da participação em ONGs ambientalistas e dos respectivos vínculos com organizações e movimentos diversificados, destacam-se aqueles casos que fazem do exercício de funções técnicas e remuneradas em tais organizações uma forma de carreira profissional. Cabe destacar que a ocupação temporária de funções remuneradas vinculadas ao desempenho de cargos técnicos e de representação nas ONGs é constante entre os militantes das mais diferentes associações, mesmo daquelas que defendem o trabalho "voluntário" e que são contrárias à utilização de funcionários remunerados e de "trabalho pago" na militância ambientalista. Isso pode ocorrer com base na utilização, como forma de salário, das remunerações concedidas pelo Estado para a representação das ONGs em conselhos e comitês estatais de proteção ambiental, como também por meio de remuneração proporcionada pela própria organização para o desempenho de funções de secretaria na entidade. Como bem salientou um dos entrevistados, o trabalho como "secretário remunerado do movimento", durante dois anos, quando teve que parar de trabalhar na área de mecânica pelo fato de mudar para o curso de Biologia, que era diurno, possibilitou-lhe certa "segurança nessa fase de migração do curso até conseguir uma bolsa". Relativamente diferenciadas desses casos são as situações em que a ocupação de funções remuneradas como técnicos de ONGs constitui a modalidade principal de atuação profissional do dirigente. Pelo que já foi exposto anteriormente em relação ao tipo de concepção de profissão e de militância, a ocupação de cargos remunerados em organizações ambientalistas não se configura apenas como uma forma de imposição de competências escolares e técnicas como os principais recursos militantes, mas, pelo contrário, tais cargos implicam sempre um trabalho preliminar de aproximação e de intensa militância na própria organização, de modo que dificilmente consiste na contratação direta ou formal em função da formação escolar e técnica requerida.

Uma primeira modalidade de carreira de dirigente ambientalista é a que resulta da intensa militância em organizações estudantis e partidárias e da articulação do engajamento associativo com a ocupação de cargos e funções remuneradas na administração pública e na burocracia estatal com 
base nos vínculos estabelecidos na militância partidária. Um trajeto ilustrativo desse padrão é o do dirigente da associação Hoctempore de Pelotas. Ele tem 34 anos, é filho único e natural de Herval, onde o pai trabalha com comércio de carro e a mãe é professora do Ensino Fundamental. Durante o Ensino Médio, deslocou-se para a cidade de Pelotas, onde se formou em Eletromecânica pela Escola Técnica e em Direito pela Universidade Federal de Pelotas. Seus pais eram adeptos do Partido Democrático Trabalhista (PDT), mas ele iniciou sua participação política por meio do grêmio estudantil e, depois, da militância no Partido dos Trabalhadores (PT), integrando a "tendência" chamada de "Democracia Socialista". Como ele mesmo salienta, foi a "participação políticopartidária” que o conduziu ao "movimento ambiental”, no sentido de que foi com base na "aproximação ideológica" com ambientalistas do Centro de Estudos Ambientais (CEA), também filiados ao PT, que ele decidiu integrar tal associação. Desse modo, durante a formação universitária ocupou posição de direção simultaneamente no Diretório Central de Estudantes (DCE), no Centro de Estudos Ambientais (CEA), além de participar da "setorial de meio ambiente" do PT em nível estadual. Foi com base nesse trajeto de militância simultânea no PT e no CEA que ocupou a pasta de Secretário Municipal de Qualidade Ambiental, durante a administração petista no município de Pelotas (2001-2004). Todavia, no processo de sucessão do então Prefeito e candidato à reeleição, tomou uma posição favorável a essa reeleição, contrariando a decisão de outros líderes do CEA que, em função de atritos com o então Prefeito, haviam decidido indicar outro candidato petista para a reeleição. Com isso, desligou-se da associação, criou a Hoctempore e, com base nos vínculos estabelecidos de longa data no PT, assumiu um cargo no Ministério do Meio Ambiente. Atualmente, ele é um dos principais articuladores de uma rede de ONGs voltadas à defesa do "bioma pampa", que já conta com a adesão de aproximadamente 80 associações ambientalistas do estado. Disso resulta uma concepção do movimento ambientalista como devendo estar associado à política partidária. Ou seja, a única forma de unificar objetivos e estratégias de luta das organizações e mobilizações ambientalistas é, necessariamente, por meio de uma orientação comum para a intervenção no âmbito da política partidária. O que fundamenta essa imbricação da "política ambiental” com a “partidária” é uma concepção militante da própria política partidária, no sentido de que esta deve estar sempre associada a outras esferas de militância (CORADINI, 2002, p. 109).

Essa combinação de militância ambientalista e partidária é muito freqüente no conjunto dos entrevistados. Todavia, em muitos outros casos são as rupturas com a militância partidária que conduz ao engajamento associativo. Esse é o caso do Presidente do Comitê Estadual da Reserva da Biosfera da Mata Atlântica (Cerbma) e do Projeto Curicaca. Ele é natural de Porto Alegre, tem 45 anos e uma trajetória social ascendente em relação ao grupo familiar. Seus pais são descendentes de imigrantes alemães e portugueses, têm apenas o Ensino Fundamental completo e são proprietários de uma pequena empresa de venda de peças de caminhão. Foi por meio da escolarização que ele começou a participar de organizações políticas: primeiro, no grêmio estudantil da escola e, depois, mais fortemente, durante todo o percurso universitário na graduação em Agronomia, que, segundo ele próprio, teve um papel decisivo na sua orientação profissional. Foi mesmo a ausência da "área social e política” que o levou a abandonar os três anos que cursara de Oceanologia para dedicar-se à Agronomia. Nesse sentido, durante o curso de Agronomia teve uma atuação no Diretório Acadêmico durante dois anos e meio, nas movimentações que uniam os estudantes com os movimentos sociais, destacando-se as mobilizações conjuntas com o MST. Além disso, mesmo que nunca tenha tido, segundo ele mesmo, uma "identidade mais fisiológico-partidária", os vínculos pessoais estabelecidos com professores e colegas filiados ao PT durante a graduação e o mestrado em Agronomia possibilitaram-lhe uma longa atuação em secretarias e órgãos da Prefeitura Municipal de Porto Alegre vinculados à defesa ambiental: primeiro, na "área de compostagem" no Departamento Municipal de Limpeza Urbana, depois na "área de poluição industrial" e em projetos de "gestão ambiental" na Secretaria Municipal do Meio Ambiente. Paralelamente à ocupação de tais cargos, ele investiu na "qualificação" profissional por meio de cursos de aperfeiçoamento no Japão e na Alemanha, alguns deles como desdobramento da própria função exercida na administração municipal. Com base nos cargos e nos cursos realizados e, principalmente, dos contatos estabelecidos com ex-colegas do curso de Oceanologia, redirecionou 
sua carreira para o "trabalho de consultoria" na "área de meio ambiente”, quando sentiu que não tinha "credibilidade" o bastante para atuar no governo e na "dinâmica pública”. Foi como desdobramento de seu trabalho de consultoria em meio ambiente que elaborou um "projeto de desenvolvimento sustentável” para o Parque dos Aparados da Serra no final de 1996 e no início de 1997 para ser implementado em Cambará do Sul, formando um grupo que resultou na criação da associação Projeto Curicaca, que preside. Desse percurso resulta uma definição da "qualificação técnica” como elemento importante para a intervenção na defesa ambiental. Todavia, tratase de uma concepção da "perícia" como devendo estar associada à esfera da política ou, mais precisamente, como a capacidade de articular o "conhecimento técnico" com os "aspectos políticos”.

Uma outra variação disso são os casos em que a entrada no ambientalismo é antecedida por uma forte participação sindical combinada com a militância partidária e com o exercício profissional em questões referentes a problemas e mobilizações ambientalistas. É o caso de um dos fundadores do Núcleo de Ecojornalistas do Rio Grande do Sul (NEJ-RS). Ele é natural do interior desse estado e sua família mudou-se para Porto Alegre assim que ele concluiu o Ensino Médio. Seu pai é caminhoneiro e a, mãe dona-de-casa; ambos têm o Ensino Fundamental incompleto. O marco inicial de sua militância foi aos 20 anos, quando o Banco Sul-Brasileiro, onde trabalhava, declarou falência. Com isso começou a participar do sindicato dos bancários e, por meio dele, também do PT, do qual se considera um dos "fundadores". Esse período de intensa militância sindical e partidária coincidiu com o momento que entrou na Faculdade de Comunicação Social da Pontifícia Universidade Católica do Rio Grande do Sul (Famecos-PUCRS), onde cursou Jornalismo de 1976 a 1980 e iniciou um período de grande participação no movimento estudantil. Como estudante de Jornalismo chegou a ser Diretor do Centro Acadêmico na PUC-RS durante a gestão de 19771978. Ao concluir a faculdade começou a participar do Sindicato dos Jornalistas do Rio Grande do Sul, fazendo parte da diretoria como Secretário, e da Central Única dos Trabalhadores (CUT), onde foi Diretor de Comunicação em 1982. No entanto, o exercício do jornalismo na empresa Zero Hora provocou uma redução da militância, pois, segundo ele, em nome da "imparcialidade da notícia”, tal empresa adotava uma postura contrária à filiação e à participação dos jornalistas em partidos e em "movimentos sociais". Por outro lado, foi com base no exercício da profissão de repórter do Zero Hora que ele entrou em contato com uma série de problemas, de mobilizações e de lideranças ambientalistas e que começou a perceber "que havia um campo fértil para sua especialização profissional”. Mais tarde desligouse dessa empresa para trabalhar na assessoria de imprensa da Procuradoria da República, a convite de uma colega de trabalho do Zero Hora. Foi nesse novo emprego que encontrou as condições para dedicar-se ao ambientalismo, filiando-se à Agapan e desenvolvendo os contatos estabelecidos com os principais líderes ambientalistas durante seu trabalho como jornalista no Zero Hora, bem como integrando as entidades de representação da categoria dos jornalistas. Com base nesses vínculos que criou o NEJ, que, segundo ele, consiste em uma "entidade não militante", mas sim "técnica e profissional”, direcionada para a discussão da "questão profissional na área ambiental junto aos jornalistas”. Trata-se de um caso em que a defesa ambiental constitui uma forma de articulação da militância sindical e partidária com a realizada no interior da "profissão" em assuntos vinculados ao exercício de determinadas categorias profissionais (Jornalismo, Direito, Biologia etc.), possibilitando reconhecimento e destaque no próprio meio profissional. Disso resulta uma definição "nãomilitante" das intervenções realizadas pela própria associação e de sua vinculação à esfera da “profissão”.

Em um outro extremo destacam-se os casos em que o percurso universitário desde o início articula-se à militância em defesa de causas ambientais e é com base nos vínculos constituídos por meio de tal militância que ocorre a ocupação de funções técnicas e profissionais em diferentes esferas de atividade. Um exemplo disso é a atual Presidenta da Agapan, que apresenta um trajeto marcado pela baixa vinculação com organizações e "movimentos sociais" e pela forte dissociação entre suas ocupações salariais, a formação universitária e a participação na associação. Ela é natural de Bagé, tem 46 anos e, quando tinha 11, sua família deslocou-se para Porto Alegre, a fim de os filhos cursarem o Ensino Superior. Seus pais têm apenas o Ensino fundamental, mas 
dispunham de boas condições financeiras para pagar os estudos universitários para todos os filhos, de modo que ela, suas três irmãs e o irmão têm formação superior. Seu pai trabalhou na assistência técnica da Brastemp até aposentar-se e a mãe era doméstica. Sua socialização política no meio familiar foi marcada pela figura de seu pai que era uma "pessoa politizada”, no sentido de que, mesmo não sendo um militante de organizações partidárias, sempre "discutia política” em casa. Segundo ela, o pai "gostava do Getúlio [Vargas]” e chegou a dar-lhe, depois, alguns documentos recortados de jornais sobre esse Presidente. No entanto, ele nunca envolveu a família na política, pois ficou atemorizado ao perceber que várias pessoas que conhecia desapareceram durante a ditadura militar. Em que pese esse tipo de vinculação do seu pai com a "política” ela nunca teve participação em qualquer tipo de organização estudantil ou partidária antes de entrar na Agapan. Pelo contrário, foi em decorrência do ingresso em tal associação que posteriormente participou do movimento estudantil e do Partido dos Trabalhadores. É que, para ela, a escola sempre "significou" um espaço de sociabilidade, para "fazer festa" e "encontrar as amizades”, chegando a repetir a quinta série do Ensino Fundamental e o primeiro ano do Ensino Médio. Concluiu a formação secundária no curso de Magistério e teve que fazer curso pré-vestibular antes de tentar o curso de Sociologia na PUC-RS e na UFRGS, passando apenas na primeira universidade e iniciando o curso em janeiro de 1983. Quando isso aconteceu, ela já participava da Agapan havia dois anos. Seu ingresso na entidade deveu-se à sua vinculação anterior com a alimentação natural e possibilitou o contato com os líderes da entidade que tiveram um papel destacado na sua criação. Todavia, sua formação universitária foi marcada, desde o início, por um grande desacordo entre o mundo do trabalho e o da militância ambientalista. Como ela mesma salienta, "era[m] três mundos na verdade que eu tinha: a faculdade; tinha o meu trabalho, que era a creche, e a Agapan, entendeu? Coisas bem distintas". Com o término da graduação, saiu do que chama de "período das creches" e tornou-se secretária remunerada da Agapan, durante três anos. Segundo ela mesma: "uma experiência maravilhosa", pois nesse período a entidade permanecia aberta durante todo o dia e atendia um público bem diversificado, além de fazer denúncias. Depois disso, foi trabalhar na implantação do projeto de coleta seletiva do Departamento Municipal de Limpeza Urbana (DMLU) de Porto Alegre a convite do então Diretor, com base na afinidade percebida no seminário "O Lixo como Instrumento de Resgate Social”, realizado no Instituto Goethe. Todavia, quando isso aconteceu, já era a representante da Agapan no Conselho Deliberativo do DMLU. Quando saiu desse departamento, ficou um tempo sem emprego, indo trabalhar com o cunhado na venda de porteiros eletrônicos, mas, não agüentando essa atividade, deixou-a: "isso aqui não tem nada a ver com o que penso". Fez um projeto na área ambiental, mas não conseguiu financiamento. Em seguida entrou na Secretaria Municipal do Meio Ambiente da Prefeitura de Porto Alegre. No período em que a entrevistamos estava desempregada, mas logo em seguida passou a ocupar a função remunerada de representante do Movimento Ecológico Gaúcho (MEG) no Programa Pró-Guaíba. Para ela, todos esses cargos e posições ocupados resultaram na possibilidade de exercício da Sociologia associada à “questão ambiental”. Nesse sentido, é com base no militância em organizações ambientalistas e nos vínculos estabelecidos com lideranças e organizações que atuam em diferentes esferas de atividade que se define a utilidade do conhecimento adquirido. Disso resulta uma concepção de que a necessidade de um maior "conhecimento técnico" das questões ambientais por parte dos militantes deve estar sempre articulada à luta pela "democratização" e pela maior participação da "sociedade civil” nas instâncias de implementação de políticas ambientais (comitês, conselhos, secretarias, audiências públicas, fórum, encontros, seminários etc.).

\section{CONCLUSÕES}

O exercício de funções peritas em ONGs insere-se em um processo mais amplo de diversificação dos padrões de reconversão da formação escolar em competências técnicas e posições profissionais. Ela remete a dinâmicas de diversificação e de intensificação das modalidades de imbricação da formação e do exercício profissional com a participação política e a militância, contribuindo, assim, para a modificação das fronteiras vinculadas ao próprio exercício profissional. Nesse sentido, os diversos padrões de carreiras de dirigentes ambientalistas, apresentados no decorrer deste trabalho, foram considerados como novas formas de inserção e 
de ocupação de postos profissionais que contribuíram para a ampliação e a expansão, tanto das possibilidades de uso da formação escolar quanto dos locais e das formas concretas de exercício profissional.

As relações entre a formação técnica e o título adquirido e o emprego ou a posição ocupacional no mercado de trabalho não ocorrem de maneira direta e automática. Tais relações são sempre mediadas tanto pelos processos e condições e processos estruturais e objetivos quanto pelos recursos, disposições e competências adquiridos pelos atores no transcurso de suas trajetórias sociais, escolares e profissionais (BOURDIEU, 1979; BOURDIEU \& BOLTANSKI, 1998). Nesse sentido, este trabalho demonstrou que as concepções de sociedade e de política características da configuração do espaço escolar e do exercício profissional no Brasil constituem um dos ingredientes principais das relações estabelecidas entre formação e perícia. Tais concepções estão fundadas em princípios que remetem à imbricação das modalidades de utilização dos recursos escolares e das competências profissionais com as dinâmicas de participação e do militância em organizações e movimentos sociais. Antes de resultar de mudanças ocorridas apenas no mundo do trabalho, pode-se ver na maior oferta de títulos escolares, associada à continuidade das concepções militantes da profissão, um dos fatores que contribuíram consideravelmente para uma diversificação maior dos padrões de atuação profissional na "área de meio ambiente".

Muito antes de ocuparem funções, remuneradas ou não, "voluntárias" ou "técnicas", em determinada ONG ambientalista, os dirigentes já contavam com um conjunto de valores, definições e recursos sociais que possibilitaram perceber em tal tipo atividade uma forma autêntica de exercício e de realização profissional. O exame dos padrões de carreiras dos dirigentes ambientalistas foi uma estratégia analítica que possibilitou apreender como determinadas formas de percepção e de avaliação relativas à atuação técnica na "área de meio ambiente" constituíramse no decorrer do tempo e sob determinadas condições sociais. Desse modo, ela põe-nos diante das disposições e dos recursos sociais que tornam possível o encontro entre determinada formação e a exercício de funções peritas. A descrição dos padrões de carreiras de dirigente ambientalista permite dar conta de como as concepções militantes que fundamentam esse tipo de atuação estão relacionadas às disposições e aos respectivos recursos adquiridos com base em vínculos estabelecidos por meio da inserção dos atores em diferentes esferas sociais no decorrer de suas trajetórias sociais e de seus itinerários escolares, militantes, ocupacionais e profissionais. Assim, foi possível demonstrar que o uso de competências técnicas na "área de meio ambiente" está respaldada em concepções, recursos e práticas profissionais que resultam da articulação entre posição social, formação universitária e inserção em diversas redes de organizações e "movimentos sociais" no decorrer de seus itinerários escolares e profissionais.

Pode-se dizer que as retribuições ou os postos alcançados por meio da militância na defesa de causas ambientais podem ser obtidos pela reconversão da formação e do exercício profissional em diferentes esferas de atividade com base nos vínculos estabelecidos pelos dirigentes durante seus itinerários escolares e profissionais com "movimentos sociais", sindicatos, partidos políticos, universidades etc. Isso as diferencia das situações em que é somente com a ascensão do ambientalismo ao poder do Estado que se constitui uma oferta maior de cargos aos militantes ambientalistas (SAINTENY, 1999, p. 188-193). Em decorrência disso, o capital coletivo das organizações que atuam na defesa do meio ambiente é bastante frágil, não devido à escassez dos postos oferecidos aos que militam nesse tipo de causa, mas porque, primeiramente, há amplas possibilidades de articulação da formação profissional com a militância política em diversas esferas de atividade, de acordo com as respectivas redes de inserção dos militantes; em segundo lugar, porque as posições acumuladas em múltiplas redes de organizações e "movimentos sociais" estão associadas a confrontos nos diferentes grupos e facções que fazem parte das mesmas.

Essas considerações colocam-nos diante de perspectivas diferenciadas também daquelas que caracterizam a institucionalização da militância ambientalista como um processo linear que resultaria de sua participação regular em instâncias formais de proteção ambiental e da imposição da formação escolar e universitária como requisito principal para o ingresso e o exercício de funções dirigentes no ambientalismo. Não estamos diante de uma situação em que a multiplicação das 
organizações e das formas de ação militante resulta de uma diferenciação entre "campo militante" e "campo político" e entre a participação associativa e a militância partidária (MATONTI \& POUPEAU, 2004). Pelo contrário, o que parece característico da situação analisada é que, a partir de final dos anos de 1980, tem havido uma forte imbricação entre a atuação dos dirigentes de organizações ambientalistas com a militância partidário e com a ocupação de postos no Estado baseada em tais vínculos políticos, pois os recursos utilizados nessa militância têm sido cada vez mais caracterizados pela intensificação da imbricação entre formação universitária e o engajamento político em diversos tipos de organizações, "movimentos sociais" e partidos políticos.

Wilson José Ferreira de Oliveira (wilson@ufpel.edu.br; mdwbg@pop.com.br) é Doutor em Antropologia Social pela Universidade Federal do Rio Grande do Sul (UFRGS) e Professor Adjunto do Departamento de Sociologia e Política da Universidade Federal de Pelotas (UFPEL).

\section{REFERÊNCIAS BIBLIOGRÁFICAS}

AGRIKOLIANSKY, E. 2002. La Ligue Française des Droits de L'Homme et du Citoyen Depuis 1945. Paris : Harmattan.

BOURDIEU, P. 1979. La distinction. Critique sociale du jugement. Paris : Minuit.

1980. Le sens pratique. Paris : Minuit.

1998. Classificação, desclassificação, reclassificação. In : CATANI, A. \& NOGUEIRA, M. A. (orgs). Pierre Bourdieu : escritos da educação. Petrópolis : Vozes.

BOURDIEU, P. \& BOLTANSKI, L. 1998. O diploma e o cargo : relações entre o sistema de produção e o sistema de reprodução. In : CATANI, A. \& NOGUEIRA, M. A. (orgs). Pierre Bourdieu : escritos da educação. Petrópolis : Vozes.

COLLOVALD, A. (dir.). 2002. L'Humanitaire ou le management des dévouements. Enquête sur un militantisme de "solidarité internationale" em faveur dur tiers-monde. Rennes : Université de Rennes.

CONNIFF, M. L. 2006. A elite nacional. In : HEINZ, F. M. (org.). Por outra História das Elites. Rio de Janeiro : FGV.

CORADINI, O. L. 1998. Panteões, iconoclastas e as Ciências Sociais. In : FELIX, L. O. \& ELMIR, C. P. (orgs.). Mitos e heróis : construção de imaginários. Porto Alegre : UFRGS.

2002. Escolarização, militantismo e mecanismos de "participação" política. In :
HEREDIA, B.; TEIXEIRA, C. \& BARREIRA, I. (orgs.). Como se fazem eleições no Brasil. Rio de Janeiro : Relume-Dumará.

DEZALAY, Y. \& GARTH, B. 2002. La mondialisation des guerres de palais. La restructuration du pouvoir d'État en Amérique Latine, entre notables du droit et "Chicago Boys". Paris : Seuil.

DREYER, L. 2004. Sinfonia inacabada. A vida de José Lutzenberger. Porto Alegre : Vidicom.

FILLIEULE, O. 2001. Propositions pour une analyse processuelle de l'engagement individuel. Revue Française de Science Politique, Paris, v. 51, n. 1-2, p. 199-215, fév.-avr. Belin.

2005. Le désengagement militant. Paris :

GALLET, G. 2002. L'expertise, outil de l'activisme environnemental chez Greenpeace France. In : HAMMAN, P. ; MÉON, J-M. \& VERRIER, B. (orgs.). Discours savants, discours militants : mélange des genres. Paris : Harmattan, p. 109-128.

GAXIE, D. \& OFFERLÉ, M. 1985. Les militants syndicaux et associatifs au pouvoir? Capital social collectif et carrière politique. In : BIRNBAUM, P. (dir.). Les élites socialistes au pouvoir. Les dirigeants socialistes face à l'État - 1981-1985. Paris : PUF.

HANNIGAN, J. A. 1995. Sociologia Ambiental. A formação de uma perspectiva social. Lisboa : Instituto Piaget. 
LECHIEN, M.-H. 2002. Aider les autres : trajectoires professionnelles, reconversions militantes et valorisation de la "personne". In : COLLOVALD, A. (dir.). L'Humanitaire ou le management des dévouements. Enquête sur un militantisme de "solidarité internationale" em faveur dur tiers-monde. Rennes : Université de Rennes.

LOUREIRO, M. R. \& PACHECO, R. S. 1995. Formação e consolidação do campo Ambiental no Brasil : consensos e disputas (1972-1992). Revista de Administração Pública, Rio de Janeiro, v. 29, n. 4, p. 137-153, out.-dez.

LOVE, J. L. \& BARICKMAN, B. J. 2006. Elites regionais. In : HEINZ, F. M. (org.). Por outra História das Elites. Rio de Janeiro : FGV.

MATONTI, F. \& POUPEAU, F. 2004. Le capital militant. Essai de définition. Actes de la Recherche en Sciences Sociales, Paris, n. 155, p. 5-11.

MEMMI, D. 1992. La competence morale. Politix, Paris, n. 17, p. 104-124.

MISCHE, A. 1997. De estudantes a cidadãos. Redes de jovens e participação política. Revista Brasileira de Educação, Rio de Janeiro, n. 5-6, p. 134-150.

OLIVEIRA, W. J. F. 2005. "Paixão pela natureza”, atuação profissional e participação na defesa de causas ambientais no Rio Grande do Sul entre 1970 e início dos anos 2000. Porto Alegre. Tese (Doutorado em Antropologia Social). Universidade Federal do Rio Grande do Sul. Disponível em : http:// www.bibliotecadigital.ufrgs.br/ da.php?nrb $=000526042 \&$ loc $=2006 \& l=b f 2$ bb6bbdcf3022e. Acesso em : 27.maio.2007.

2007. Formas precárias de emprego, atuação em ONG's e inserção profissional. Sociedade em Debate, Pelotas, v. 13, n. 1, p. 141160, jan.-jun.
OLLITRAULT, S. 1996. Science et militantisme : les transformations d'une échange circulaire. Le cas de l'ecologie française. Politix, Paris, n. 36, p. 141-162.

2001. Les écologistes français, des experts en action. Revue Française de Science Politique, Paris, v. 51, n. 1-2, p. 105-130, fév.avr.

PASSY, F. 1998. L'action altruiste. Paris : Droz.

PÉCAUT, D. 1990. Os intelectuais e a política no Brasil : entre o povo e a nação. São Paulo : Ática.

SAINT-MARTIN, M. 1999. Uma "boa" educação. Educação \& Sociedade, Campinas, v. 20, n. 66, p. 104-122, abr. Disponível em : http:// www.scielo.br/pdf/es/v20n66/v20n66a5.pdf. Acesso em : 15.mar.2008.

SAINTENY, G. 1999. Logiques d'engagement et logiques de rétribution au sein de l'écologisme français. Cahiers Internationaux de Sociologie, Paris, v. CVI, p. 175-200.

SAWICKI, F. 1997. Les réseaux du Parti Socialiste. Sociologie d'un milieu partisan. Paris : Belin.

SIMÉANT, J. 2001. Entrer, rester en humanitaire : des fondateurs de MSF aux membres actuels des ONG médicales françaises. Revue Française de Science Politique, Paris, v. 51, n. 1-2, p. 47-72, fév.-avr.

SIMÉANT, J. \& DAUVIN, P. 2002. Le travail humanitaire. Les acteurs des ONG, du siege au terrain. Paris : Sciences Po.

WAGNER, A.-C. 2004. Syndicalistes européens. Les conditions sociales et institutionnelles de l'internationalisation des militants syndicaux. Actes de la Recherche en Sciences Sociales, Paris, n. 155, p. 13-34.

\section{OUTRAFONTE}

Revue Française de Science Politique. 2001. Paris, v. 51, n. 1-2, fév.-avr.

Artigo modificado por solicitação do editor em (Abril/2009). 